\title{
COMMENTS
}

\section{Probable Cause for Tax Seizure Warrants}

\author{
Erin Suzanne Enright $\dagger$
}

Under the liberal self-reporting framework of our federal tax system, the Secretary of the Treasury enjoys broad summary collection powers. ${ }^{1}$ The most potent weapon in this statutory arsenal is 26 U.S.C. $\S 6331$, providing that a taxpayer with assessed but unpaid tax liabilities is subject to levy upon all of his property. Additionally, the Internal Revenue Service may seize this property "by any means." The Supreme Court has endorsed the constitutionality of these summary seizures since $1856,{ }^{3}$ and has declared that administrative proceedings for collection of revenue satisfy due process, reasoning that prompt, post-seizure judicial review is available to taxpayers. ${ }^{4}$

While ruling that the seizures themselves were constitutional, the Court had not addressed the legality of searches of private property accompanying tax seizures until G.M. Leasing Corp. v.

$\dagger$ A.B. 1982, Princeton University; J.D. Candidate 1988, The University of Chicago.

- The Internal Revenue Code authorizes the Secretary to determine and assess all unpaid income taxes. 26 U.S.C. $\S \S 6201-04$ (1982)(all references to the United States Code are to Title 26 unless otherwise indicated). Under $\$ 6303$, the Secretary must send notice of an assessment and make a demand for payment to the taxpayer within 60 days of the assessment. Section 6321 provides that if any taxpayer liable for taxes neglects or refuses to pay after demand, the amount due shall support a lien in favor of the United States upon all of the taxpayer's real and personal property.

${ }^{2}$ Section 6331 authorizes the Secretary to levy upon all of the taxpayer's property if the taxpayer does not pay within 10 days of notice and demand. A "levy" is "[t]he obtaining of money by legal process through seizure and sale of property." Black's Law Dictionary (5th ed. 1979). As clarified in $\S 6331(\mathrm{~b})$, "the term 'levy' as used . . . includes the power of distraint and seizure by any means." Sections $6331(\mathrm{a})$ and (d)(3) provide an exception from the 10-day waiting period for cases in which the IRS believes that the collection of taxes is in jeopardy. In these emergency situations, $\$ 6861$ permits the IRS to assess and collect the tax immediately, subject to certain restrictions.

${ }^{3}$ See Murray's Lessee v. Hoboken Land \& Improvement Co., 59 U.S. 272 (1856).

4 See Phillips v. Commissioner of Internal Revenue, 283 U.S. 589, 595-601 (1931). 
United States ${ }^{5}$ in 1977. The IRS previously had interpreted the Internal Revenue Code as sanctioning administrative methods for seizures pursuant to $\S 6331$, without concern for the possible fourth amendment implications of searches for liened property. ${ }^{6}$ In G.M. Leasing the Supreme Court imposed a warrant requirement on non-exigent tax seizures that involve the entry into and search of private premises. The Court failed, however, to give concrete guidance concerning the standards for issuing such a warrant.

Lower courts uniformly have interpreted G.M. Leasing as imposing a probable cause requirement on tax seizure warrants, ${ }^{7}$ working from the explicit language of the fourth amendment. ${ }^{8}$ Courts have taken two approaches, though, with regard to the appropriate standard of probable cause for these warrants. Some federal courts have espoused use of the traditional probable cause standard, which would require assessment of testimony presented to a magistrate to determine whether it demonstrates a "fair probability" that the assets sought are both legally seizable and currently at the site to be searched. ${ }^{9}$

Other courts, in contrast, have embraced a probable cause test that focuses on the existence of administrative or legislative guidelines to curtail the discretion of government officers executing tax seizure warrants. ${ }^{10}$ This "administrative" warrant standard for probable cause was first developed in Camara $v$. Municipal Court, ${ }^{11}$ where the Supreme Court held that a warrant is required for public safety inspections. The Court at the same time eased the

s 429 U.S. 338 (1977).

- Prior to G.M. Leasing, the IRS "had for years pursued the administrative practice, pursuant to 26 U.S.C.A. $\$ 7301$ (a), of seizing any property found in the possession, custody or control of the person against whom the tax had been imposed." Matter of Carlson, 580 F.2d 1365, 1369 (10th Cir. 1978).

? See United States v. Condo, 782 F.2d 1502, 1504-05 (9th Cir. 1986); Matter of Campbell, 761 F.2d 1181, 1186 (6th Cir. 1985); United States v. Shriver, 645 F.2d 221, 222 (4th Cir. 1981); Carlson, 580 F.2d at 1376-82; Matter of Tax Indebtedness of Stephens, 54 Bankr. 626, 627 (D.Mont. 1985); Matter of Gerwig, 461 F.Supp. 449, 451 (C.D.Cal. 1978); Matter of Brickner, 453 F.Supp. 91, 92 (E.D.Wisc. 1978).

- The fourth amendment of the U.S. Constitution states:

The right of the people to be secure in their persons, houses, papers, and effects, against unreasonable searches and seizures, shall not be violated, and no warrants shall issue, but upon probable cause, supported by oath or affirmation, and particularly describing the place to be searched, and the persons or things to be seized.

- See Condo, 782 F.2d at 1504-05; Stephens, 54 Bankr. at 627; Gerwig, 461 F.Supp. at 451; Brickner, 453 F.Supp. at 93.

10 See Campbell, 761 F.2d at 1186; Shriver, 645 F.2d at 222-23; Carlson, 580 F.2d at 1381; Matter of Brown, 55 Am.Fed.Tax Rptr.2d 85-462, 85-463 (C.D.Utah 1984); Bormann v. Tomlin, 461 F.Supp. 193, 196-98 (S.D.IIl. 1978).

${ }^{21} 387$ U.S. 523 (1967). 
probable cause standard for those inspections. Here, the Court found probable cause satisfied by reasonable administrative or legislative regulations that restrict the state's discretion in making inspections.

Part I of this comment discusses the G.M. Leasing decision and outlines the rules it established for tax seizures. Part II sketches the contours of the two probable cause standards currently in use: that applied to traditional searches and that used in administrative inspections. The section also illustrates the traditional and administrative probable cause standards in the tax warrant context. Part III analyzes the lower courts' interpretations of G.M. Leasing, setting out their divergent approaches to the probable cause question. Part IV compares tax seizures to both criminal searches and administrative searches and concludes by demonstrating the need for the traditional standard of probable cause in $\S 6331$ cases.

\section{G.M. Leasing v. United States}

The Supreme Court first examined the constitutionality of warrantless IRS searches pursuant to $\S 6331$ in G.M. Leasing $v$. United States. ${ }^{12}$ The case involved a jeopardy assessment against a delinquent taxpayer, George Norman, Jr., and his alter ego, G.M. Leasing Corporation. In satisfaction of outstanding levies, the IRS seized several luxury cars belonging to G.M. Leasing that were located in public areas. Some days later, IRS officers seized and proceeded to search a cottage that G.M. Leasing used as its business offices.

The Supreme Court granted certiorari on the question whether the fourth amendment barred the warrantless searches and seizures of the automobiles and the cottage. The Court found there was probable cause that G.M. Leasing's assets were seizable. Moreover, the company did not allege the absence of probable cause that it owned the automobiles or that its offices would contain other seizable property. "[T]he only questions before the Court [were] whether warrants were required to make 'reasonable' either the seizures of the cars or the entry into and seizure of goods in the cottage."1s

The Court found the automobile seizures constitutional on the ground that they occurred on public premises and consequently

13 Id. at 351. 
did not involve an invasion of privacy. The Court cited Murray's Lessee v. Hoboken Land \& Improvement Co. ${ }^{14}$ to justify warrantless seizures under the tax laws, and as that case similarly involved a "public" seizure, ${ }^{18}$ G.M. Leasing held that both cases were "governed by the same principles." ${ }^{16}$ This aspect of the decision can best be read as a statement that under prevailing fourth amendment doctrine, taxpayers do not enjoy a legitimate expectation of privacy with regard to seizable property located in "public" areas. ${ }^{17}$

By contrast, the Court found that the cottage had greater fourth amendment protection, and held that the IRS's entry into it invaded Norman's privacy. The Court declared that "except in certain carefully defined classes of cases, a search of private property without proper consent is 'unreasonable' unless it has been authorized by a valid search warrant."18 The Court rejected the IRS's assertion that case law provided an exception to the general warrant requirement for tax collection, and held that in the absence of "clear evidence" of such a loophole, warrantless tax searches were unjustified. ${ }^{19}$ The Court also rejected the IRS's argument that the statute attempted to create a statutory exemption to the warrant requirement for tax seizures. ${ }^{20}$

While the decision clearly established that $\S 6331$ searches must be under warrant, G.M. Leasing shed no light on the probable cause guidelines which magistrates should use in issuing the

1459 U.S. 272 (1856).

16 The seizure in Murray's Lessee was a transfer of title to property.

16429 U.S. at 351-52.

17 See Kat2 v. United States, 389 U.S. 347 (1967).

18 G.M. Leasing, 429 U.S. at 352-53, quoting Camara v. Municipal Court, 387 U.S. 523, 528-29 (1967). The Court also refused to extend the "pervasively regulated business" exception to tax enforcement. G.M. Leasing, 429 U.S. at 353-54. As the Court has explained this exemption, "[t]here are certain 'relatively unique circumstances'. . .in which consent to regulatory restrictions is presumptively concurrent with participation in the regulated enterprise." Delaware v. Prouse, 440 U.S. 648, 662 (1979), quoting Marshall v. Barlow's, Inc., 436 U.S. 307,313 (1978). The Court has identified three major industries as "pervasively regulated." See United States v. Biswell, 406 U.S. 311 (1972) (firearms); Colonnade Catering Corp. v. United States, 397 U.S. 72 (1970) (liquor industry); and Donovan v. Dewey, 452 U.S. 594 (1981) (underground and surface mines).

10 G.M. Leasing, 429 U.S. at 355.

${ }^{20}$ The Court read $\$ 6331(\mathrm{~b})$, which allows "distraint and seizure by any means," to authorize "the use of every means to deprive the taxpayer of use, enjoyment, or title to property." The Court held that such language nonetheless "does not refer to warrantless intrusions into privacy." G.M. Leasing, 429 U.S. at 356-57. The Court refused to interpret the statute more broadly, as the IRS urged, declaring that "[t]he respondents offer no legislative history in support of their reading of $\S 6331$, and to give the statute that reading would call its constitutionality into serious question." Id. at 358. 
warrants, as the taxpayer in the case did not contest the probable cause issue. ${ }^{21}$ Confusion among lower courts quickly arose in light of the Supreme Court's landmark search warrant decisions in Camara v. Municipal Court ${ }^{22}$ and See v. City of Seattle. ${ }^{23}$ These cases set forth two different standards for probable cause analysis, amd lower courts have split over which standard is appropriate for tax seizures.

\section{Probable Cause}

\section{A. The Traditional Standard}

Surprisingly few enunciations have been made in the case law of the precise dimensions of "probable cause" for search warrants. ${ }^{24}$ The problem has two elements: first, one must answer the question "probable cause to determine what?" and, second, one must determine the satisfactory level of proof.

The solution to the first inquiry can be summarized as follows: when appearing before a magistrate, "the state must show probable cause to believe that: (1) a crime has been committed, and (2) a specific object of the state's interest exists (evidence, a suspect, or a material witness) and (3) the intrusion will secure the object."25 The latter two considerations reflect a concern that the object or person sought will be found at the site to be searched. ${ }^{26}$ To ensure

21 Id. at 351.

22387 U.S. 523 (1967).

${ }^{23} 387$ U.S. 541 (1967).

24 "The amount of probability necessary to satisfy probable cause has resisted quantifcation." Comment, The Theory of Probable Cause and Searches of Innocent Persons: The Fourth Amendment and Stanford Daily, 25 UCLA L.Rev. 1445, 1448 n.9 (1978). A number of decisions have simply projected the baseline notion of probable cause used for arrest warrants onto the search context, citing Carroll v. United States, 267 U.S. 132 (1925).

Probable cause exists where 'the facts and circumstances within [the officers'] knowledge and of which they had reasonably trustworthy information [are] sufficient in themselves to warrant a man of reasonable caution in the belief that' an offense has been or is being committed.

Brinegar v. United States, 338 U.S. 160, 175-76 (1949), quoting Carroll, 267 U.S. at 162. See also Draper v. United States, 358 U.S. 307, 313 (1959).

${ }^{25}$ Comment, 25 UCLA L.Rev. at 1454 (cited in note 24) (footnote and emphasis omitted).

${ }^{28}$ See Steagald v. United States, 451 U.S. 204, 213 (1981)("A search warrant. . is issued upon a showing of probable cause to believe that the legitimate object of a search is located in a particular place."); Comment, Search and Seizure in the Supreme Court: Shadows on the Fourth Amendment, 28 U.Chi.L.Rev. 664, 687 (1961).

It is interesting to note that this emphasis on the probability of success of the search in effect sets the countervailing public and private interests in the search on an equal footing. One commentator has proposed a variation on Judge Hand's formula in United States v. Carroll Towing Co., 159 F.2d 169, 173 (2d Cir. 1947), to illustrate this calculation. According 
that the object or person will be there, the magistrate must look for signs of staleness of prior police research. As one court has noted,

delay in seeking and obtaining a search warrant may invalidate it. . . . Obviously, a highly incriminating or consumable item of personal property is less likely to remain in one place as long as an item of property which is not consumable . . . or not particularly incriminating. ${ }^{27}$

While the elements which must be shown to be supported by probable cause are well-established, the quantum of proof that the government must provide is less evident. Rather than drawing a "more probable than not" bright line, courts and commentators have preferred to blur the test. ${ }^{28}$ In addressing the issue, Judge Learned Hand proposed that "[n]o more is required than a fair presumption." "29 Professor LaFave has claimed that

[t]he requirement of probable cause does not mean that there must be "a showing of guilt beyond a reasonable doubt"; what is needed is "reasonable grounds for suspicion, supported by circumstances sufficiently strong in themselves to warrant a cautious man in the belief."

to this author,

the concept of probable cause is best characterized as an evidentiary standard that embodies a balance among three variables, probability, cost, and value. This balance may be formulated as $V P>C$, where $V$ represents the value of the search to society, $P$, the probability of success, and $C$, the cost of the intrusion into privacy.... [In criminal cases] the cost $(C)$ and value $(V)$ variables are held constant.

Note, Camara, See, and Their Progeny: Another Look at Administrative Inspections Under the Fourth Amendment, 15 Colum.J.L. \& Soc.Prob. 61, 79-80 (1979) (footnotes omitted).

Consequently, the seriousness of the crime which engenders the search is irrelevant and the level of intrusiveness of the search is generally ignored. The only "weighing" or "balancing" which normally occurs in a criminal probable cause assessment is to determine the odds that the person, property or evidence sought will actually be found. There are, of course, some extremely intrusive searches in which the Court has amended its policy of disregarding the degree of invasion which a particular search would impose on the individual. See, for example, Winston v. Lee, 470 U.S. 753, 766-67 (1985) (surgery to remove a bullet from defendant's abdomen as evidence of commission of a shooting held an "unreasonable search").

${ }^{27}$ United States v. Steeves, 525 F.2d 33, 38 (8th Cir. 1975).

28 "The Supreme Court . . . has refrained from expressing the required level of certainty in mathematical terms, relying instead on a scale of less exact but more familiar legal terminology." Ronald J. Bacigal, The Fourth Amendment in Flux: The Rise and Fall of Probable Cause, 1979 U.Ill.L.Forum 763, 771.

29 United States v. Old Dominion Warehouse, Inc., 10 F.2d 736, 738 (2d Cir. 1926).

so Wayne R. LaFave, Search and Seizure: "The Course of True Law . . . Has Not . . . Run Smooth", 1966 U.Ill.L.Forum 255, 259, citing People v. York, 29 Ill.2d 68, 193 N.E.2d 773 (1963) and People v. Lavendowski, 329 Ill. 223, 160 N.E. 582 (1928). 
A number of other analysts have equated probable cause with a
"substantial probability" test."

\section{B. The Camara Standard For Administrative Searches}

The Camara v. Municipal Court of San Francisco ${ }^{32}$ and See $v$. City of Seattle ${ }^{33}$ cases, decided on the same day in 1967, imposed a warrant requirement on administrative searches under municipal housing and fire codes. Roland Camara refused to permit a San Francisco housing official to make a routine annual inspection of

sx See People v. Glen, 30 N.Y.2d 252, 259, 282 N.E.2d 614, 617 (1972); Comment, 28 U.Chi.L.Rev. at 687 (cited in note 26); Yale Kamisar, Wayne R. LaFave, and Jerold H. Israel, Modern Criminal Procedure 280 (6th ed. 1986).

In attempting to apply this theoretical level of proof in a meaningful manner, cases which rest probable cause on an informant's tip provide a helpful analogy. Although the framework used in the tip cases may not fit perfectly when the supporting affidavit in a tax seizure case is based solely on IRS agents' investigation, there are two reasons why the approach is fruitful. First, at least some of the $\S 6331$ warrants issued will rely on information derived from non-IRS sources. Second, while in most instances government officials can be presumed to act in good faith, those few occasions when their activities are malicious justify at least a cursory magisterial review of the veracity of affidavits. See Fulton Market Cold Storage Co. v. Cullerton, 582 F.2d 1071 (7th Cir. 1978) (allegations of intentional overassessment of taxes by county assessor); North American Cold Storage Co. v. County of Cook, 468 F.Supp. 424 (N.D. Ill. 1979) (same).

Illinois v. Gates, 462 U.S. 213 (1983), represents the prevailing interpretation of the standard under which magistrates should determine the existence of probable cause in the informant context. The Gates Court explicitly rejected the two-pronged analysis stemming from Aguilar v. Texas, 378 U.S. 108 (1964), and Spinelli v. United States, 393 U.S. 410 (1969). Under the Aguilar-Spinelli test, a magistrate first looked to the credibility of the witness or affiant as evidenced by past honest tips. Second, the magistrate evaluated the basis of the informant's knowledge in order to determine the likely accuracy of the witness' information on the particular occasion. Gates, 462 U.S. at 229 n.4. Proponents saw the two separate inquiries as providing assurance both that the informant was, in general, not a liar (and thus that his testimony should be given credence in this case), and that there was some reason to believe that, in addition to the informant's history of honesty, he could demonstrate some objective support for trusting this particular story.

The Gates Court declared that "the 'two-pronged' test has encouraged an excessively technical dissection of informants' tips." Id. at 234. The opinion then proposed a "totalityof-the circumstances" measure to replace the credibility and basis of knowledge inquiries. Under this new standard,

[t]he task of the issuing magistrate is simply to make a practical, common-sense decision whether, given all the circumstances set forth in the affidavit before him, including the 'veracity' and 'basis of knowledge' of persons supplying hearsay information, there is a fair probability that contraband or evidence of a crime will be found in a particular place.

Id. at 238.

${ }^{32} 387$ U.S. 523 (1967).

3s 387 U.S. 541 (1967). See is important because it extended the warrant requirement to searches of commercial structures. The Court's analysis in See, however, proceeds along the line developed in Camara, and thus the rest of the discussion in this section will focus only on Camara. 
his residence. After two further denials of official requests to enter his building, Camara was charged with a criminal violation of $\S 507$ of the San Francisco Municipal Code for refusing to allow authorized employees to inspect his premises. Noting that the fourth amendment incorporates a presumption in favor of warrants, ${ }^{34}$ the Court expressly overruled Frank v. Maryland which, only eight years earlier, had declared warrantless administrative searches valid, stating that these searches touched "at most upon the periphery" of fourth amendment concerns.35 The Frank Court had concentrated on the civil nature of regulatory inspections, effectively holding that only criminal searches enjoyed fourth amendment safeguards.

Camara turned its back on the Frank framework, claiming that "[i]t is surely anomalous to say that the individual and his private property are fully protected by the Fourth Amendment only when the individual is suspected of criminal behavior." 36 The Court went on to discuss the potential for abuse of discretion in warrantless field inspections and, in support of the need for warrants, said that "broad statutory safeguards are no substitute for individualized review."37 Finally, the Court dismissed the government's argument that a warrant requirement would frustrate the public interest in administrative searches, holding that the burden of obtaining prior judicial approval was not fatal to the societal purposes underpinning the searches. ${ }^{38}$

The most critical aspect of Camara for the purposes of the tax seizure cases is the Court's treatment of probable cause for the

s4 Camara, 387 U.S. at 528-29.

ss 359 U.S. 360,367 (1959).

se Camara, 387 U.S. at 530. The warrant requirement established by Camara implemented the recommendations of critics of Frank. Justice Douglas, in his Frank dissent, quoted Chief Judge Prettyman's opinion in District of Columbia v. Little, noting that "[t]he basic premise of the prohibition against searches was not protection against self-incrimination; it was the common-law right of a man to privacy in his home." Frank, 359 U.S. at 377 (Douglas dissenting), quoting Little, 178 F.2d 13, 16-17 (D.C.Cir. 1949), aff'd on other grounds, 339 U.S. 1 (1950). Another commentator claimed that, under the Frank regime, "[t]hose types of governmental invasions of privacy most likely to involve the law-abiding person are subjected to the least restraint, those directed primarily against persons suspected of crime to the greatest." Edward L. Barrett, Jr., Personal Rights, Property Rights, and the Fourth Amendment, 1960 S.Ct.Rev. 46, 71-72. It is not clear, however, that analysts taking Barrett's view would be as enthusiastic about the Camara Court's loosening of the probable cause standard. See, for example, Comment, State Health Inspections and "Unreasonable Search": The Frank Exclusion of Civil Searches, 44 Minn.L.Rev. 513, 532 (1960) ("[O]nly a very serious threat to community health. . .could justify compromise with the principle that the need for each intrusion must be proved by the intruder.").

${ }^{37}$ Camara, 387 U.S. at 533.

${ }^{38}$ Id at $532-33$. 
newly imposed warrants. The Court began its probable cause discussion by noting that "[i]n cases in which the Fourth Amendment requires that a warrant to search be obtained, 'probable cause' is the standard by which a particular decision to search is tested against the constitutional mandate of reasonableness."39

In some sense, it is a misnomer to label the administrative standard "probable cause" at all, as it addresses the neutrality and reasonableness of guidelines, rather than the likelihood of finding evidence. One suspects that the Supreme Court and, in turn, the lower courts, ${ }^{40}$ use the term in order to satisfy the command of the fourth amendment that "no warrant shall issue, but upon probable cause." Naturally, confusion has arisen from this distortion of the commonly understood meaning of probable cause. The Court has not eased this puzzlement, and in fact has aggravated it, through pronouncements in other fourth amendment contexts. In South Dakota v. Opperman, for example, the Court declared that

[t]he standard of probable cause is peculiarly related to criminal investigations, not routine, noncriminal procedures. . . . The probable-cause approach is unhelpful when analysis centers upon the reasonableness of routine administrative caretaking functions. ....41

Ignoring these problems in its refashioning of "probable cause," the Camara Court claimed that "there can be no ready test for determining reasonableness other than by balancing the need to search against the invasion which the search entails." ${ }^{\prime 42}$

In applying this standard to the housing inspections in Camara, the Court cited three factors that combined to make the area searches reasonable. First, "such programs have a long history of judicial and public acceptance."43 Second, these inspections were considered to be the only effective means of satisfying the strong public interest in health and safety. Finally, the Court declared that because the housing code searches were "neither personal in nature nor aimed at the discovery of evidence of crime, they involve a relatively limited invasion of the urban citizen's privacy."44

39 Id. at 534 .

10 All of the lower courts which have faced the tax seizure problem, see note 7, have discussed the warrant standard in terms of probable cause.

11428 U.S. 364,370 n.5 (1976).

12 Camara, 387 U.S. at 536-37.

43 Id. at 537.

44 Id. It is ironic that this rationale is very similar to the explanation the Frank Court 
On the strength of these factors, the Camara Court stated that it is obvious that "probable cause" to issue a warrant to inspect must exist if reasonable legislative or administrative standards for conducting an area inspection are satisfied with respect to a particular dwelling. Such standards . . . may be based on the passage of time, the nature of the building . . . , or the condition of the entire area, but they will not necessarily depend upon specific knowledge of the condition of the particular dwelling. ${ }^{45}$

Camara thus established a two-step analysis for ascertaining whether an administrative standard of probable cause should apply. First, the "reasonableness" test specified by the Court must be satisfied. Second, if "reasonableness" is established, the magistrate must be confident that "reasonable legislative or administrative standards for conducting an area inspection" exist to serve as a buffer against governmental agents' discretion in undertaking

gave for refusing to require warrants for administrative inspections. See v. City of Seattle, 387 U.S. at 554 (Clark dissenting) (making a similar observation about the Frank majority).

For a prescient article written in the interim between Frank and Camara, see Comment, Administrative Inspections and the Fourth Amendment: A Rationale, 65 Colum.L.Rev. 288, 291-92 (1965) (footnotes omitted):

The basic flaw in the fourth amendment approach is that the established standard of probable cause . . . would have to be greatly diluted to accommodate the municipal need . . . for several periodic inspections. . . . Relaxation of the standard of probable cause would be compelled by the need to avoid [the] consequences [of hampering these inspections]. But once the standard were relaxed, the routine issuance of warrants would compromise any effective protection against improper searches. . . . [I]n an ex parte proceeding . . . the existence of a spiteful motive is hardly likely to come to the attention of the magistrate. . . . Moreover, whether the application is 'based on caprice' or on a 'plan of spot checks or area-by-area searches' would be extremely difficult to determine.

A later critic succinctly stated that "[i]n the context of administrative searches, the warrant requirement adds little or no protection of privacy beyond that already provided by the fourth amendment's reasonableness requirement." Note, Administrative Searches and the Fourth Amendment: An Alternative to the Warrant Requirement, 64 Cornell L.Rev. 856, 861 (1979).

45 Camara, 387 U.S. at 538. The probable cause standard adopted in Camara echoed Justice Douglas's Frank dissent and Justice Brennan's dissent from the result in Ohio ex rel. Eaton v. Price, 364 U.S. 263 (1960), which similarly upheld the constitutionality of warrantless administrative searches. As Justice Douglas wrote:

Where considerations of health and safety are involved, the facts that would justify an inference of 'probable cause' to make an inspection are clearly different from those that would satisfy such an inference where a criminal investigation has been undertaken. Experience may show the need for periodic inspections of certain facilities without a further showing of cause to believe that substandard conditions dangerous to the public are being maintained. The passage of a certain period without inspection might of itself be sufficient in a given situation to justify the issuance of a warrant.

Frank, 359 U.S. at 383 (Douglas dissenting). 
health and safety searches.

In determining the precise contours of the reasonableness test, one can look to the Camara Court's rationales of historical acceptance, high public need, and low privacy intrusiveness. The first asserted criterion seems clearly inadequate to repel a constitutional challenge. As Professor LaFave has noted,

the continued operation of [periodic and area inspection] programs may show only a "history of acquiescence." [S]imilar or even greater evidence of judicial and public acceptance of long-used procedures has not deterred the Court from finding those procedures constitutionally defective. . . . ${ }^{46}$

The strength of the second argument, that the public interest in the enforcement of regulations justifies reducing the level of probable cause, depends on how one measures "public need." When one compares society's interest in building code enforcement with its concern for the criminal law's effectiveness, it is difficult to maintain that the public's desire to uphold building codes clearly outweighs its desire to catch criminals.

LaFave points out an interesting offshoot from this reasoning, however. He asserts that the public interest justification is more compelling when a reduced probable cause standard is viewed as the only practical means of facilitating, say, building code enforcement. Administrative violations often take place on private premises, removed from the public's and the inspector's surveillance. Criminal activities, on the other hand, typically involve "aggressive conduct, most often occurring in public places, which usually leaves a trail of discernible facts. . . . Even in the case of so-called victimless crimes, including those committed within private premises, the police are not without means of detection." LaFave notes that victimless crimes "require customers, and thus the way is open for the use of informants and undercover agents." ${ }^{37}$ This reasoning suggests that the existence of alternative mechanisms for ensuring compliance cuts against the need for using the administrative probable cause standard, and instead creates a presumption in favor of the traditional test.

The third factor in the Camara analysis is the lower intrusiveness of regulatory inspections. Several commentators on the re-

18 Wayne R. LaFave, Administrative Searches and the Fourth Amendment: The Camara and See Cases, 1967 S.Ct.Rev. 1, 14, quoting Frank, 359 U.S. at 384 n.2 (Douglas dissenting).

17 Id. at 15-16 (footnotes omitted). 
duced probable cause standard have identified elements which combine to make administrative searches less oppressive. These characteristics include the absence of stigma created by inspections; the fact that regulatory searches are normally conducted during the day by unarmed officials, rather than police; the shorter duration of the sweeps; and the fact that generally nothing is seized. ${ }^{48}$

As generalizations, these factors do seem to differentiate administrative searches from their criminal counterparts. Yet they cannot stand alone in defining "intrusiveness." An additional component of the search must be scrutinized in order to apply the appropriate probable cause gauge, a component variously labeled as the "routine" nature of the search or the level of "hostility" involved in the inspection. ${ }^{49}$ The concern here is whether the search is aimed at a suspected individual or is part of a neutral series of similar inspections. If there is particularized suspicion, the low intrusiveness assumption of Camara dissolves, and the administrative standard should not be applied to the search involved.

In sum, then, the Camara "reasonableness" rationale boils down to two considerations. The first is whether enforcement of an administrative policy would be stymied by use of the traditional search standard. The second is the generality, or conversely the particularity, of the suspicion that prompts the search. ${ }^{50}$

The subsequent Supreme Court cases applying the administrative probable cause standard have followed this framework imperfectly. In Marshall v. Barlow's, Inc. ${ }^{51}$ the Court imposed a warrant requirement on searches pursuant to $\S 8(a)$ of the Occupational Safety and Health Act of $1970 . .^{52}$ Officials of the Occupational Safety and Health Administration (OSHA) previously had made warrantless inspections of employers' plants, but the Court invalidated this procedure, citing Camara as precedent for mandatory warrants. The Court noted that

probable cause justifying the issuance of a warrant may be

\footnotetext{
18 See Note, 15 Colum.J.L. \& Soc.Prob. at 82-83 (cited in note 26); LaFave, 1967 S.Ct.Rev. at 19. See Part IV for a more detailed discussion of these considerations in the tax seizure warrant context.

10 See Camara, 387 U.S. at 530; Note, Administrative Search Warrants, 58 Minn.L.Rev. 607, 641 (1974); Charles R. McManis and Barbara Mayes McManis, Structuring Administrative Inspections: Is There Any Warrant for a Search Warrant?, 26 Am.U.L.Rev. 942, 964 (1977).
}

so See LaFave, 1967 S.Ct.Rev. at 20 (cited in note 46).

31436 U.S. 307 (1978).

8229 U.S.C. $\$ 657(\mathrm{a})$ (1982). 
based not only on specific evidence of an existing violation, .. . [but also may exist where] a specific business has been chosen for an OSHA search on the basis of a general administrative plan for the enforcement of the Act derived from neutral sources. ... .

Barlow's thus failed to differentiate between those situations involving particularized suspicion, which would not satisfy Camara's "reasonableness" test, and those falling into a routine inspection framework, which might pass that test. Consequently, the decision seriously erred in its interpretation of Camara's theory of probable cause.

Michigan v. Tyler ${ }^{54}$ and Michigan v. Clifford ${ }^{55}$ dealt more effectively with the threshold Camara question. In pronouncing a formula for searches of fire-scorched premises, the Tyler Court drew a three-tiered system of analysis. First, the Court declared that "an entry to fight a fire requires no warrant." circumstances of the fire legitimate the fire fighters' entry. Second, the Tyler majority addressed administrative searches to ascertain the cause of a fire. In this context, the Court imposed a warrant requirement, stating that officials must have a magistrate verify the propriety of the governmental intrusion under the Camara standard. ${ }^{57}$ Finally, the Court held that if investigators aim "to gather evidence for a possible prosecution [for arson], they may obtain a warrant only upon a traditional showing of probable cause applicable to searches for evidence of crime."158

This tripartite analysis highlights that the existence of particularized suspicion is a key factor in the Court's determination of the probable cause standard required for a search. Where the individual is not confronted with governmental hostility and suspicion, the Court uses the Camara exception. The presence of a particu-

\footnotetext{
s3 Barlow's, 436 U.S. at 324, 320-21 (footnote omitted).

s4 436 U.S. 499 (1978).

ss 464 U.S. 287 (1984).

se Tyler, 436 U.S. at 511.

87
}

The magistrate's duty is to assure that the proposed search will be reasonable, a determination that requires inquiry into the need for the intrusion on the one hand, and the threat of disruption to the occupant on the other. For routine building inspections, a reasonable balance between these competing concerns is usually achieved by broad legislative or administrative guidelines. . . . In the context of investigatory fire searches, which are not programmatic but are responsive to individual events, a more particularized inquiry may be necessary.

Tyler, 436 U.S. at 507.

s8 Id. at 512. 
larized investigation, on the other hand, mandates the traditional probable cause standard. ${ }^{\text {9 }}$

\section{The Standards As Applied to Tax Warrants}

Before analyzing the post-G.M. Leasing treatment of probable cause in the tax seizure context, it is useful to outline how the administrative and traditional probable cause standards would operate in $\S 6331$ cases. Under the Internal Revenue Code, there are certain prerequisites to any seizure of a taxpayer's lienable assets. First, the Commissioner is authorized to determine and assess all unpaid income taxes. ${ }^{60}$ Under $\S 6303$, a notice of this assessment and a demand for payment must be transmitted to the delinquent taxpayer within 60 days. If the taxpayer does not come forth with the money within 10 days of notice and demand, the Commissioner may levy upon all of the taxpayer's property and may sanction a seizure. ${ }^{61}$

In deciding whether probable cause exists under the administrative "probable cause" standard, Camara and later cases suggest that a court should make a categorical, rather than a case-by-case, assessment of whether three requirements are met. In the tax seizure context, the court should ascertain first whether use of the traditional probable cause standard would stymie tax enforcement. Second, the magistrate should inquire whether this type of search is characterized by an absence of particularized suspicion. If both preliminary reasonableness requirements are met, then the court should ask whether Congress, through $\S 6331$ or other provisions of the Internal Revenue Code, or the Secretary of the Treasury, through regulations, has promulgated neutral guidelines for IRS agents making tax seizures under a warrant.

If any prong of this test is not satisfied, use of an administrative standard would violate the principles set forth in Camara. Further, even if tax seizure warrants properly could be treated under the administrative rubric, the magistrate must in each case ascertain whether the Commissioner has followed the steps outlined in $\S \S 6201-6331$, the Code's assessment and collection

so Official suspicion of a citizen is not nil in the administrative context either. In the fire scenario, for instance, if investigators are unaware of the cause of a blaze, there normally will be a small, but nonetheless positive, probability that arson was at work. The difference between the administrative and criminal cases, and thus the distinction between the existence or absence of particularized suspicion, is one of degree.

oo See $\$$ 6201-04.

o1 See $\$ 6331$. 
procedures.

If tax seizures fall under traditional probable cause analysis, one court has proposed that warrant applications must

enable the judge to make an independent determination of whether probable cause exists to believe that: (1) An assessment of tax has been made against the taxpayer; (2) Notice and demand have been properly made; (3) The taxpayer has neglected or refused to pay said assessment within ten days after notice and demand; and (4) Property, subject to seizure, presently exists at the premises sought to be searched and that said property either belongs to the taxpayer or is property upon which a lien exists for the payment of the taxes. ${ }^{62}$

The fourth factor obviously is the crux of probable cause analysis under the traditional standard. The traditional probable cause standard is met if, and only if, the magistrate discerns a "fair probability" that seizable assets currently exist at the site to be searched.

\section{Lower Court Treatment of Probable Cause}

The lower court cases pertaining to the probable cause standard for tax seizure warrants have split fairly cleanly into two camps, one following the Camara administrative test and the other adhering to traditional search criteria. In general, the applications of the standards have been impressionistic. Like the Supreme Court in Barlow's, the courts first "place" tax seizures into either the administrative or the criminal category, and then evaluate the affidavit under the test that follows "logically" from this placement.

In reviewing the courts' analyses it is useful to test whether the administrative probable cause standard is applicable. If the tax warrant cases satisfy the reasonableness and neutral guidelines requirements of Camara, use of the administrative measure will be supportable. If, on the other hand, these requirements cannot be met, the traditional probable cause standard appears constitutionally mandated.

\section{A. The "Reasonableness" Test}

Several lower courts have espoused the administrative probable 
cause standard ${ }^{63}$ for tax seizure warrants on the ground that the use of the traditional standard would eviscerate tax code enforcement. At least one decision, Matter of Carlson, has asserted that since G.M. Leasing, IRS agents were unlikely to pursue non-public seizures without judicial backing, ${ }^{84}$ and declared that "if such enforcement measures are unavailable, the end result would probably lead to effective frustration of the mandates of the code relating to tax payments." ${ }^{\prime 65}$ This reasoning superficially appears to meet the Camara requirement that statutory enforcement be frustrated by use of the traditional probable cause standard.

The argument is flawed, however, because the court made no attempt to analyze the avenues open to the IRS to identify seizable property, and thereby successfully carry out $\S 6331$ seizures within the bounds of the traditional probable cause standard. The court also failed to compare the relative difficulties of criminal code and tax code enforcement, and did not explain why tax searches would be blocked by the traditional probable cause measure where criminal investigations would not. ${ }^{66}$ Despite the weakness of this argument, the Fourth Circuit in United States $v$. Shriver subsequently endorsed it, stating that "[t]he [tax warrant] proceeding should not have been converted into an adversary one or prolonged over a period of years while taxes presumptively due and owing remain

6s Cases adopting the administrative probable cause standard are Matter of Campbell, 761 F.2d 1181 (6th Cir. 1983); United States v. Shriver, 645 F.2d 221 (4th Cir. 1981); Matter of Brown, 55 Am.Fed.Tax Rptr.2d 85-462 (C.D.Utah 1984); Bormann v. Tomlin, 461 F.Supp. 193 (S.D.Ill. 1978); Matter of Carlson, 434 F.Supp. 554 (D.C.Colo. 1977), rev'd, 580 F.2d 1365 (10th Cir. 1978).

of Presumably because to do so would be unconstitutional. Prior to Carlson, the IRS had employed "writs of entry" as a mechanism for evading the warrant requirement. See Harry D. Shapiro and Robert K. Briskin, Sup. Ct., in G.M. Leasing, Restricts IRS Property Seizures Without Search Warrants, 46 J.Tax'n 218, 220-21 (1977). Carlson declared that the court no longer elected to use "the IRS term 'entry order,' but, instead, the district court's reference to the need for a "warrant," 580 F.2d at 1377, effectively closing the possible loophole that worried Shapiro and Briskin. Subsequent cases treat requests for entry as warrants, regardless of the label attached to them. See, e.g., Gerwig, 461 F.Supp at 451.

ss Carlson, 580 F.2d at 1381.

so

Both the civil and criminal laws respond to urgent public needs, and it does not suffice to say, as some have, that the level of public need differs because civil law enforcement requires searches and seizures on a broad scale, necessitating a more relaxed standard. The argument that the Amendment must be reinterpreted to accommodate enforcement techniques developed without thought to the Constitution permits legislators and administrators to redefine reasonableness at will. . . Law enforcement, in other words, should work within bounds set by the Fourth Amendment, not vice versa.

Note, The Civil and Criminal Methodologies of the Fourth Amendment, 93 Yale L.J. 1127, 1138-39 \& n. 61 (1984) (the final sentence of the quoted passage is from the footnote). 
uncollected." The Shriver court inexplicably assumed that use of the traditional standard of probable cause would transform the ex parte warrant application process into an adversarial one.

Perhaps the unstated concern of the Shriver court was that use of the traditional standard would delay seizure of assets by the IRS, running the risk that tax evaders could secret portable possessions. This concern alone, however, would not overcome the flaw in the courts' reasoning in this area. The Supreme Court has indicated that, absent exigent circumstances, the fourth amendment requires the government in criminal cases to secure a private area suspected to contain evidence and to obtain a warrant before searching it, even if there is a fear that evidence is in jeopardy. ${ }^{68}$ Neither Carlson nor Shriver explain why the Court's apparent preference for less-intrusive enforcement alternatives in the criminal context should not obtain in the tax context.

The cases adopting the administrative standard also have failed to confront the second prong of Camara, which would ask in this context whether $\S 6331$ searches are of low intrusiveness or are characterized by individualized suspicion. These courts have emphasized instead the origin of the levy and seizure process in the Internal Revenue Code and the administrative enforcement of seizures by the IRS Commissioner. The Tenth Circuit in Carlson, for example, stated that the Internal Revenue Code provides that delinquent taxes are to be collected by "administrative means." The court then flatly declared that "[w] hat is not involved here, in the 'probable cause' meaning is that degree of 'probable cause' required to support a criminal search warrant. . . ."80 Carlson's acceptance of Congress's "administrative" categorization of tax en-

675 F.2d at 222.

e8 Vale v. Louisiana, 399 U.S. 30 (1970). See also Segura v. United States, 468 U.S. 796 (1984) (upholding search subsequent to arrest where officers secured premises for 19 hours while awaiting search warrant).

69 580 F.2d at 1368, 1377. The court discussed Camara and See, implicitly linking the two decisions to G.M. Leasing by noting that in establishing the warrant requirement, the Court had used a quotation from Camara that, with narrow exceptions, "a search of private property without proper consent is 'unreasonable' unless it has been authorized by a valid search warrant." G.M. Leasing Corp. v. United States. 429 U.S. 338, 358 (1977), quoting Camara v. Municipal Court, 387 U.S. 523, 528-29 (1967). Carlson saw this reference as aligning the cases, and claimed that "none of these opinions [Camara, See, or G.M. Leasing] identify the specifics of 'probable cause' requirements in support of search warrants in furtherance of administrative processes authorized by statute." Carlson, 580 F.2d at 1377. Notably, the language cited by the Carlson court to draw its analogy between G.M. Leasing and Camara involved explanation of the general preference for warrants under the fourth amendment; it did not arise in the context of Camara's discussion of probable cause standards. See Camara, 387 U.S. at 528-29. 
forcement as determinative of the applicable probable cause standard gives the legislature a power of definition that allows it to bend the fourth amendment to suit its prerogatives. This view appears incorrect, as Congress's burden of justifying its laws on constitutional grounds should not vary depending on its characterization of its own actions.

The opinions following the traditional probable cause methodology, in contrast, have emphasized that tax searches raise fourth amendment concerns that are much the same as those in criminal investigations. Matter of Brickner exemplifies this viewpoint. The case involved an IRS attempt to obtain a warrant to search the home of the father of a delinquent taxpayer, Gerald Brickner, for property owned by the younger Brickner which was subject to seizure. The IRS argued that an administrative search standard should apply to the entry order. The court spurned this line of reasoning, claiming that " $[t]$ he present case . . . is quite unlike the situation in Camara. . . . [T] his case involves the consideration of probable cause allegations that pertain to a particular individual rather than to a general area or a general plan."70

\section{B. Neutral Guidelines}

Once courts advocating use of the Camara standard have concluded that tax searches meet the reasonableness test, they neglect to scrutinize $\S 6331$ searches for the existence of neutral guidelines that act to cabin IRS officials' discretion. The court in Bormann $v$. Tomlin, ${ }^{71}$ for example, focused on the statutory basis of the seizure procedure, rather than looking for specific administrative regulations governing that procedure. The court used the fact that revenue laws" and the housing code in Camara were both "statutes which attempt to authorize warrantless searches or intrusions on private property" to infer that the Camara standard was appropriate for the warrant in question. ${ }^{78}$ The decision made no mention of the necessity for neutral guidelines restraining the tax collector.

Despite its reliance on the Camara standard, the Fourth Circuit in Shriver did not concern itself with the neutrality of the IRS

70453 F.Supp. 91,93 (E.D.Wisc. 1978).

71461 F.Supp. 193 (S.D. Ill. 1978).

72 Bormann arose under Illinois Revenue Code provisions similar to those of the Internal Revenue Code.

73461 F.Supp. at 196-98. "In Barlow's Inc., the Court reaffirmed Camara and See that probable cause in the criminal law sense is not required for issuance of a warrant." Id. at 198. 
regulations. The court stated that in tax seizure warrant cases,

[j]udges are simply to determine whether the application and supporting affidavit showed probable cause to enter, search for, and levy upon personal property in aid of summary collection of assessed and unpaid taxes. . . . Since we detect no deficiency in the application or the affidavit, the warrant should have issued. . . .74

The affidavit submitted in Shriver stated that taxes had been assessed against the taxpayers, that notification and demand had been made, that no payment had been forwarded, and that on the taxpayers' farm "there were trucks, farm equipment and excavating equipment belonging to the taxpayers." No more detailed verification of these assertions was offered. The decision approvingly noted that "[t]he [IRS] agents act under administrative instructions designed to protect taxpayers from oppressively excessive levies, but they must be left with a substantial amount of discretion. . ..."75

By stressing the statutory and civil form of $\S 6331$ at the expense of the substantive constraints imposed by the Internal Revenue Code and Treasury Department regulations, the cases applying the administrative standard have departed from the emphasis in Camara and Barlow's on meaningful protection of individuals' privacy. ${ }^{76}$ These lower courts' views create a curious rubber stamp function for the magistrate, whose only role becomes to affirm that statutory technicalities have been satisfied, rather than to assure the sanctity of fourth amendment privileges. Justice Clark, in dissent in Camara and See, forecast this very danger in the Court's new probable cause formulation. Clark maintained that the administrative standard

would permit the issuance of paper warrants . . . with probable cause based on ... standards as set out in municipal codes, and with warrants issued by the rubber stamp of a willing magistrate. . . . These boxcar warrants will be identical as to every dwelling in the area, save the street number itself. I daresay they will be printed up in pads of a thousand or more-with space for the street number to be inserted-and

${ }^{74} 645$ F.2d at 222.

${ }^{35}$ Id. at $222-23$.

${ }^{78}$ These cases' reliance on the "civil" or "administrative" nature of tax enforcement searches also highlights that Frank's civil/criminal dichotomy for fourth amendment interpretation may not be as obsolete as Camara proclaimed. See Camara, 387 U.S. at 530. 
issued by magistrates in broadcast fashion as a matter of course. ${ }^{77}$

If meeting the Revenue Code requirements were sufficient to validate a $\S 6331$ search, then the need for a warrant would dissolve entirely. A search violating collection procedures could be challenged as illegal simply on the ground that the IRS failed to follow its own policies.

Several lower courts that have rejected the administrative probable cause measure for tax warrants have highlighted this rubber stamp danger. As the Gerwig court noted,

the district court cannot, of course, allow IRS agents total, uncontrolled discretion, once validly inside the premises pursuant to a warrant, to rummage everywhere in search of seizable items. . . . [W] [Wile clearly it would be too burdensome to require . . . that the IRS list specifically what they plan to seize and be limited solely to that list, some restraint is necessary. . . . [T] tations protecting the taxpayer's privacy from unnecessary intrusions beyond those needed to allow the IRS agents enough discretion to seize. ${ }^{78}$

United States $v$. Condo further elaborated this theme, stating that

[t]he IRS application must have sufficient specificity to enable the judge to make an independent determination of whether probable cause exists and to prevent the agents from having uncontrolled discretion. ... Gerwig properly stresses the need for restraints similar to those imposed on police executing search warrants. . . .79

\section{A Critical Evaluation of the Two Standards for Tax WARRANTS}

\section{A. The Importance of the Standard}

The likely unavailability of an effective remedy for a fourth amendment violation in tax seizure cases heightens the importance of identifying and applying the correct probable cause standard when the warrant is issued. The most visible fourth amendment remedy, the exclusionary rule, may be worthless in the majority of

\footnotetext{
77 See v. City of Seattle, 387 U.S. at 547-48, 554 (Clark dissenting).

78 F.Supp. at $452-53$.

782 F.2d 1502, 1505 (9th Cir. 1986).
} 
$\S 6331$ cases. In most instances, seizure of the taxpayer's assets is the final step in the IRS's recoupment scheme. As seizure is not a means of procuring evidence for a subsequent trial, the exclusionary rule would not deter the IRS from fourth amendment breaches.

Even in cases which are targeted for future prosecution, it is unclear whether the Supreme Court would apply the exclusionary rule. In United States $v$. Janis, ${ }^{80}$ the Court refused to exclude evidence that had been illegally seized by state police agents in an action by the IRS to establish a tax deficiency against Janis. The precise implications of Janis are elusive, as a major factor in the decision was a belief that preventing the IRS's use of the evidence would not deter the unlawful conduct of state police. While it is therefore possible that the Court would apply the exclusionary rule where the IRS was itself the offending governmental organ, the likelihood of this occurring is unknown. The Janis Court specifically stated that "[i]n the complex and turbulent history of the [exclusionary] rule, the Court never has applied it to exclude evidence from a civil proceeding, federal or state." 81

Additionally, the taxpayer pursuing the exclusion remedy would face a formidable burden of proof. United States v. Leon ${ }^{82}$ makes clear that the Court will not exclude evidence obtained in a search which was undertaken pursuant to an invalid warrant unless the government agents executing the inspection knew or should have known that the warrant was inadequate. ${ }^{83}$ The taxpayer would face only a slightly less demanding burden of proof in a Bivens ${ }^{84}$ action against the individual IRS employees. As the lower court on remand in Bivens noted, "it is a defense to allege and prove [that the federal agent acted in] good faith and reasonable belief in the validity of the . . . search. . . ."8s

A citizen whose property was seized erroneously could recover his assets in a refund action, after showing that the property was not subject to a lien. It is highly unlikely, however, that a taxpayer would recover property seized with liens outstanding against it. The strong public policy in favor of tax enforcement makes it improbable that a court would force the IRS to return what are, in

80 428 U.S. 433 (1976).

82 Id. at 447 (1976) (footnote omitted).

82468 U.S. 897 (1984).

${ }^{83}$ Id. at $922-25$ (1984).

s. Bivens v. Six Unknown Fed. Narcotics Agents, 403 U.S. 388 (1971).

${ }^{85}$ Bivens v. Six Unknown Named Agents of Fed. Bur. of Narc., 456 F.2d 1339, 1348 (2d Cir. 1972). 
effect, government assets in order to remedy a fourth amendment breach.

\section{B. The Determination of a Standard}

In order to assess the appropriate probable cause standard for tax seizures, it is useful to review the purposes and justifications underlying Camara's redefinition of the term "probable cause." As explained in Part II above, in determining whether the administrative probable cause standard should apply, the Camara "reasonableness" test concentrates on whether the traditional probable cause measure would frustrate effective statutory enforcement and whether the target of the search is routinely selected from the general population, or is identified as being a likely offender through a special investigation.

Upon close scrutiny, tax seizures fail to meet the criteria set out for using this reduced standard of probable cause. First, a variety of alternate methods of tax code enforcement exist, which reduces the likelihood of frustration of code enforcement through use of the traditional probable cause standard. IRS officials can monitor ownership records such as automobile registration and property rolls, and can use informants and surveillance of businesses and residences to ascertain the existence of the taxpayer's property.

Moreover, on a theoretical level, the problems faced in tax seizures and searches are distinguishable from those encountered in administrative inspections. In tax seizures, the culprit has been identified before probable cause must be proved, since the IRS initially must determine who is a delinquent taxpayer before undertaking investigation. Consequently, in order to satisfy the traditional probable cause standard for this group, the government must complete only one task: gathering specific information on an already-identified individual.

This limited undertaking contrasts with the two rigorous requirements that would face officials attempting to satisfy the traditional standard for, say, a housing code inspection. The agent in the latter case first would have to find a method of accurately discerning "offenders" among the general public, and then would have to amass inculpatory evidence against the individuals so targeted. As Justice Stevens noted in his Barlow's dissent, the first of these two requirements would virtually guarantee the rejection of a warrant application:

The routine OSHA inspections are, by definition, not based 
on cause to believe there is a violation on the premises to be inspected. Hence, if the inspections were measured against the requirements of the Warrant Clause, they would be automatically and unequivocally unreasonable. ${ }^{86}$

Because both types of warrants require particularized suspicion, tax seizure warrants pose the same problems for IRS officials as criminal warrants pose for police in criminal investigations. Courts have not found the burdens imposed by the traditional standard to be intolerable for criminal law enforcement; neither should Internal Revenue Code enforcement be stymied by the stricter probable cause inquiry.

Tax seizure searches also fail to satisfy the second Camara reasonableness prong. These invasions cannot be expected to be brief in duration or narrow in scope; because the IRS can lay claim to virtually all of the taxpayer's property, these intrusions are likely to be lengthy and wide-ranging. These considerations give rise to a forceful pragmatic argument in favor of the traditional probable cause measure in the tax context, namely, the difficulty of drawing principled, substantive distinctions between non-routine civil searches and criminal searches. ${ }^{87}$

${ }^{86}$ Marshall v. Barlow's, Inc., 436 U.S. at 326 (Stevens dissenting). Justice Stevens' proposed solution to his dilemma is to evaluate administrative inspections solely under the reasonableness clause of the fourth amendment. He argues that "[t]he Court's approach disregards the plain language of the Warrant Clause" by distorting the definition of probable cause:

[T] he general warrant, not the warrantless search, was the immediate evil at which the Fourth Amendment was directed. . . . Fidelity to the original understanding of the Fourth Amendment leads to the conclusion that the Warrant Clause has no application to routine, regulatory inspections of commercial premises. If such inspections are valid, it is because they comport with the ultimate reasonableness standard of the Fourth Amendment.

Id. at 327-28.

87 This view contrasts with that expressed in Comment, The Permissible Scope of OSHA Complaint Inspections, 49 U.Chi.L.Rev. 203 (1982), where the author concludes that the appropriate standard of probable cause in OSHA complaint inspections is that used in the line of cases originating with Terry v. Ohio, 392 U.S. 1 (1968):

Under the reasonable belief standard, a warrant should issue if the employee's allegations are credible and support a reasonable belief that the violation will be found in the place alleged. ... Although establishment of an intermediate level of probability for complaint inspections further complicates administration of the warrant requirement, such variation is the inevitable result of applying a reasonableness standard to the warrant clause in administrative warrant cases.

Comment, 49 U.Chi.L.Rev, at 232-33 (footnotes omitted). In arriving at this standard for probable cause, the Comment did not scrutinize the relative merits of the possible approaches. While conceding that "[i]n degree of intrusiveness, the complaint inspection resembles a criminal search," the author simply proclaimed that "[b]ecause the violations sought in the complaint inspection are not criminal, however, a less stringent showing of 
The abdication of the stricter standard of probable cause in tax searches, which are nearly as intrusive on individual privacy as are searches for criminal evidence, could lead to a serious and undeserved expansion of the use of Camara warrants. The process of balancing competing governmental and privacy interests tends to undervalue individuals' privacy stakes. ${ }^{88}$ As many of the administrative warrant proceedings are ex parte, magistrates rely on government officials to supplement their own assessment of citizens' interests. This systemic bias should be ameliorated in the context of intrusive civil searches, of which tax seizures on private premises are but one example, ${ }^{88}$ by establishing the stronger presump-

probability than that required for criminal searches is appropriate." Id. at 231 (footnote omitted). This assertion disregards the Camara Court's rejection of the Frank criminal-civil dichotomy as being "anomalous." See Camara, 387 U.S. at 530.

s8 "[T]he structure of the balancing test inclines courts to hear the needs of law enforcement more clearly than the claims of privacy: Frequent chances for error systematically weaken privacy." Note, 93 Yale L.J. at 1143 (cited in note 66).

s? Searches with a high level of intrusiveness include Immigration and Naturalization Service (INS) sweep searches of businesses to identify illegal aliens based on informants' tips; OSHA employee complaint investigations, in which officials enter an employer's plant looking for violations which have been reported by an employee; and the fire investigation searches discussed in Michigan v. Tyler, 436 U.S. 499 (1978), and Michigan v. Clifford, 464 U.S. 287 (1984).

On INS sweep searches, see Blackie's House of Beef, Inc. v. Castillo, 659 F.2d 1211 (D.C.Cir. 1981), where the court, emphasizing the "civil" nature of INS sweeps, "reasoned that since the detention and deportation of illegal aliens have long been regarded as civil in nature and not analogous to criminal investigations, the Camara standard applied automatically." Note, Blackie's House of Beef, Inc. v. Castillo: A Need for a Closer Look at Administrative Probable Cause, 17 New Eng.L.Rev. 1373, 1389 (1982), citing Blackie's House of Beef, 659 F.2d at 1218. See also Kotler Industries v. I.N.S., 586 F.Supp. 72,75 (N.D.Ill. 1984). But see Illinois Migrant Council v. Pilliod, 531 F.Supp. 1011, 1020 (N.D.Ill. 1982):

[A]dministrative warrants may not be used by INS to justify the seizure of persons. Assuming arguendo that Blackie's was correctly decided and that INS may utilize an administrative warrant to enter and search a given commercial location, such a warrant does not authorize the search or seizure of persons found on the premises.

For analyses of OSHA complaint warrants, see Comment, 49 U.Chi.L.Rev. 203 (cited in note 87); Note, Administrative Agency Searches since Marshall v. Barlow's Inc.: Probable Cause Requirements for Nonroutine Administrative Searches, 70 Geo.L.J. 1183 (1982). The latter Note concurs with the conclusions reached in this Comment. See id. at 1199.

Lower court cases in these areas which have applied the Camara standard have been as confounding as those which have done so in the tax context. Following Barlow's, the majority of lower courts which have grappled with OSHA inspections stemming from employee complaints have refused to use the traditional probable cause standard. For example, the court in Matter of Establishment Inspection, Etc., 589 F.2d 1335 (7th Cir. 1979), applied the administrative standard to an OSHA search of the employer's factory following an employee tip. The court noted the statement in Barlow's that the Secretary's "entitlement to inspect will not depend on his demonstrating probable cause to believe that conditions in violation of OSHA exist on the premises. Probable cause in the criminal sense is not required." Id. at 1388, quoting Barlow's, 436 U.S. at 320 (emphasis in Establishment Inspection). The Establishment Inspection court then noted that 
tion in favor of the citizen that the traditional standard of probable cause affords.

Another argument in favor of using the traditional probable cause standard is that there is solid evidence that protection against customs and revenue searches was a major impetus to the drafting of the fourth amendment. The Supreme Court, when extending a warrant requirement to tax searches, noted that "one of the primary evils intended to be eliminated by the Fourth Amendment was the massive intrusion on privacy undertaken in the collection of taxes pursuant to general warrants and writs of assistance." 90 Some historians ascribe at least partial responsibility for the creation of the constitutional search and seizure protection to the overreaching practices of colonial customs inspectors and revenue collectors. As one commentator notes, "[i]t was through efforts to control abusive enforcement of tax laws that limits were first placed on search and seizure."91

While this historical insight is not dispositive, the genesis of the fourth amendment in the excesses of colonial revenue enforcement supports the application of the traditional probable cause measure to tax seizure warrants. The framers' perception of tax collectors' searches as acutely intrusive underscores the centrality of IRS inspections to traditional fourth amendment concerns, and points to the need for an independent magisterial review of tax warrants.

This analysis leads to the conclusion that no set of IRS administrative guidelines could ever surmount the Camara reasonable-

[b]ecause of the aforementioned quote from Barlow's, negating the requirement of probable cause in the criminal sense, and because the OSHA inspections involved in these appeals are similar to those in Camara and See, the less stringent probable cause test must be applied here.

Establishment Inspection, 589 F.2d at 1339. Burkart Randall Div. of Textron, Inc. v. Marshall, 625 F.2d 1313, 1317 (7th Cir. 1980), and Marshall v. Horn Seed Co., Inc., 647 F.2d 96, 102-03 (10th Cir. 1981), employ the same superficial reasoning.

${ }^{80}$ G.M. Leasing, 429 U.S. at 355.

91 Jacob W. Landynski, Search and Seizure and the Supreme Court 25 (1966). See also Telford Taylor, Two Studies in Constitutional Interpretation 26-27 (1969), citing L. Kinvin Wroth and Hiller B. Zobel, eds., 2 Legal Papers of John Adams 107 (1965):

Parliamentary enactments of 1660 and 1662 authorized the issuance of 'writs of assistance' by the Court of Exchequer, for the seizure of any 'prohibited or uncustomed' goods, to effect which the constables could break and enter houses, shops, and any 'other Place.' It was under the authority of the 1662 statute that the writs of assistance were issued which were the subject of the great case before the Superior Court of Judicature of the Province of Massachusetts Bay in 1761. In its course James Otis made the famous argument denouncing these writs which, according to John Adams, "breathed into this nation the breath of life.' 
ness threshold. Yet, even were this not the case, the present $\S 6331$ does not meet Camara's further requirement of "neutral" guidelines, as the statute does not ensure that the behavior of IRS agents will be non-discretionary. The language of the provision imposes no limits on IRS seizures, but rather explicitly endorses seizure "by any means." The Supreme Court has acknowledged this absence of legislative oversight, stating that

[i]f more than one location is involved, the Secretary will choose which dwelling will be invaded. If property is to be found both in public places and in private areas, the Secretary may choose which to seize. This hardly can be called a restraint on discretion. ${ }^{22}$

It is, to say the least, ironic that after the explicit pronouncement that the tax seizure statute is an inadequate buffer against governmental prerogative, any lower court would find that tax warrants met Camara's requirement of neutral guidelines.

\section{Conclusion}

As they are broad in scope, often lengthy, involve the threat of seizure, and hinge on IRS officials' discretion as to which sites to search and which items to seize, searches under $\S 6331$ of the Internal Revenue Code demand the rigorous review provided by the traditional probable cause inquiry. Tax seizure warrants fail to match the profile of searches calling for the administrative probable cause standard under the framework developed in Camara and its progeny.

Although collection of revenue is concededly an important social goal, it is absurd to claim that tax collection is, in effect, necessarily a more pressing public aim than the effective enforcement of criminal laws. At the same time, searches pursuant to $\S 6331$ are hostile and non-routine, and thus should be considered more intrusive than housing inspections or similar health and safety searches. Finally, the seizure statute does not constrain the state's discretion in implementing tax warrants through neutral guidelines.

Both historical evidence and pragmatic concerns argue in favor of the use of the traditional probable cause standard in the tax seizure context. The criminal search standard, under which the individual exposed to a search pursuant to $\S 6331$ benefits from the full probable cause scrutiny that other discretionary, specific, and 
"hostile" intrusions are given, is compelled by the fourth amendment shield of privacy. 